\title{
Autofiction and the Diary: The Radicalization of Autofiction in Works by Hervé Guibert and Christine Angot
}

\author{
Sam Ferguson
}

I recently had the chance to take an overview of the development of autofiction in French writing when I contributed a chapter on autofiction to the Cambridge History of the Novel in French (Ferguson 2021). Without elaborating any new theories or definitions (there are too many already), I took stock of how this part of literary history has been told: among other things, I found that Serge Doubrovsky's role in the creation of autofiction has been exaggerated, partly because of the need to keep telling the story of how he invented the word "autofiction" itself; that Roland Barthes' role in this history has been underplayed; and that autofictional writing in French is divided between two general approaches undertaken by two generations, respectively-one born before the Second World War, the other born after it-with Hervé Guibert (1955-1991) playing a pivotal role in the shift from one generation of autofictional writers to another. In the present chapter, I shall supplement these findings with a single broad claim: that autofiction moved from having an orientation toward

S. Ferguson $(\bowtie)$

Slyne, UK

(C) The Author(s) 2022

A. Effe, H. Lawlor (eds.), The Autofictional, Palgrave Studies in

Life Writing, https://doi.org/10.1007/978-3-030-78440-9_14 
autobiography in the work of the earlier generation to having an orientation toward the diary in the work of the later generation, who came to prominence in the 1990s, and that this change can be seen as a radicalization of the practices and desires of autofiction. This claim notably runs counter to the common assumption that, "mimicking the chronological progression of traditional autobiographical form, autofiction is normally retrospective, an older self remembering or revisiting their past life" (Arnaud Schmitt, this volume, 92). This is not just a question of whether autofictional works use the form of an autobiography or a diary, but rather of whether they use autobiographical modes of writing or diaristic modes of writing, each of them with their own practices, values, and preconceptions about truth and the sort of life that is worth writing. These two modes can result in many different written forms, and even co-exist in a single work.

To illustrate this reorientation of autofiction toward diaristic modes of writing, I shall examine works by two authors: Hervé Guibert, who seems to inaugurate the second generation of autofictional writers with his hugely successful work À l'ami qui ne m'a pas sauvé la vie (To the Friend Who Did Not Save My Life, [1990b] 1999), and Christine Angot, who became an emblematic figure of autofiction following the publication of L'Inceste (Incest, 1999). However, while I would argue that the two landmark works mentioned above demonstrate a diaristic orientation in their mode of autofictional writing (without using a strictly dated diaristic form), for each of these writers it will be more revealing to examine an earlier work in which they use the diary far more explicitly as part of an experimentation that leads them to their own individual approach to autofiction. In Guibert's case, the diary is an important element for many works in his overall project to reveal himself as fully possible (Genon 2014, 52-57), but his relatively early work Voyage avec deux enfants (Journey with Two Children, 1982) has been identified by critics as one in which a complex use of diary writing allows him to carry out his own characteristic type of autofiction for the first time (Genon 2014, 69; Sarkonak 2000, 116). Angot's career path was quite different, moving from primarily fictional novels toward autofiction, but again a work in diary form, Léonore, toujours (Léonore, Always, 1993) was crucial for working toward her own, equally distinctive form of autofictional writing (Huet 2018, 199-200; Picard-Drillien 2010, 22). Guibert and Angot, in these two radically different works, find in the diary the resources to challenge established 
literary forms, change their own practice as writers, and forge new approaches to writing the self.

Before discussing these two works in turn, it will be useful to situate them more broadly in the context of a change from one generation of autofictional writers to another, and to engage with some critical reflections which have come to almost the opposite conclusion to my own. In articles on this very question, Michel Braud and Philippe Lejeune have found that the diary, far from being an important element in autofictional writing, is difficult to reconcile with a combination of truth and fiction, and is even fundamentally opposed to fiction itself.

\section{The Two Generations}

Our perception of the literary history of autofiction depends on the extension that we give to the phenomenon "autofiction" as an object of study, ranging from, at one extreme, the history of the word itself (necessarily beginning in 1977 with Doubrovsky's Fils and including only those writers who positively embraced the term, which would therefore exclude both Guibert and Angot), to the other extreme, where it becomes a "prodigious tool for reading" (Colonna 2004, 13-14), ${ }^{1}$ a concept used to examine the permutations of truth and fiction in writing going back to ancient literature. Without implying any judgment of these two positions or the many "affordances" in between (to use a term from the title of the present collection), my own interest is in a phenomenon that lies between these two extremes: a nebulous but identifiable trend connected to both autobiography and the novel from the 1970s onward, and which has become a major part of contemporary literature. From this perspective, despite the diversity of the works that are included within this phenomenon (some of which are labeled as autofiction by critics but not by the authors themselves), it divides into two quite distinct generations, each marked by a series of family resemblances.

The earlier generation consists of writers born before the Second World War, including Roland Barthes, Alain Robbe-Grillet, Marguerite Duras, and Serge Doubrovsky. These writers participated in the general exclusion of the psychological and writing subject in the 1960s, and then the return of the subject in the 1970s and 1980s through various innovative forms. A common theme is a recognition of the inherent fictionality of autobiography's retrospective narrative account of the past, and an exploration of the implications of assuming this fictionality, using resources drawn from 
the novel. For this generation, the combination of truth and fiction was always paradoxical and a fascinating theoretical problem to be explored.

For the generation born after the war, including Guibert, Angot, Philippe Forest, Nina Bouraoui, Camille Laurens, and Chloé Delaume, the combination of real life and fiction is less of a theoretical problem. Interweaving the two comes more naturally to them, they are more likely to perceive life itself as being suffused with fiction in tangible ways (such as the role of phantasies in our everyday lives), and they are more personally implicated in the process and results of their writing, whether through the imbrication of their public, private, and written personas (as is notably the case for Angot) or through the demanding experiments to which they subject themselves (especially for Delaume). I am also proposing here that the work of this later generation involves more diaristic writing, without necessarily adopting a strictly dated diary form: this would include, for example, works that give an ongoing account of some sort of personal project or experiment with an unforeseeable outcome, and where the writing process over a period of time is itself a significant part of the experience. Whereas the findings of the earlier generation of writers regarding the fictional nature of autobiographical retrospection can now be taken for granted, the second generation makes more extensive use of diaristic writing practices that, owing to their grounding in everyday life, retain a strong connection to reality and give rise to new modalities of truth and fiction.

But the chronology of these two generations is complex: Guibert, who was born in 1955 and died in 1991 from complications related to AIDS and a suicide attempt, now appears as an autofictional writer in keeping with the later generation, with diaries featuring heavily throughout his work, yet his literary experimentation with truth and fiction goes back to his collection La Mort propagande (Propaganda Death) published in 1977 , the very same year as the creation of the word "autofiction" by Doubrovsky. There is considerable overlap between the work of these two groups, which is why it is more appropriate to speak of generations of writers than of clusters of works limited to a certain period of time. Another reason for this complicated chronology is that autofiction was not just created once and then imitated, but was invented over and over again by different writers in the course of their own experimentation. The works that I shall discuss, Voyage avec deux enfants and Léonore, toujours, offer two distinct examples of these individual inventions of autofiction. 


\section{Diaries ANd Autofiction}

My claim that the second generation of autofictional writers had a strong orientation toward the diary is in sharp contrast to the reflection that critics have devoted thus far to the relation between the diary and autofiction, and while I disagree with those critics' overall conclusion that the diary is fundamentally inimical to fiction, they make some valuable distinctions. The two foremost critics to have addressed this question-Michel Braud and Philippe Lejeune-approach the matter with certain preconceptions and even a certain ideology that is common in the academic study of life-writing.

This ideology is most obvious in Lejeune's article "The Diary as 'Antifiction"' (2009, first published in French in 2007). He admits that he created the word "antifiction" to characterize the diary because of his "irritation" with autofiction itself (201). His perspective is typical of a certain hostility toward fiction in general from certain parts of the study of life-writing, a sense that it threatens the continued existence of nonfictional forms. Lejeune considers that writers of autobiography have been tempted to brand their work as autofiction in order to gain some of the literary prestige associated with fiction and the novel (Marie Darrieussecq has also made this claim, as discussed by Alison James in the present volume, 46-47), thereby undermining the pedigree of autobiography itself (Lejeune [2007] 2009, 203). He also concedes that autobiography tends toward fiction because of the need to create a structured narrative of past events and to impose a coherent form on one's personality, but sees the diary as resisting this tendency. As he puts it, "autobiography lives under the spell of fiction; the diary is hooked on truth" (201). His argument regarding the diary runs as follows: given that the diary is written in ignorance of how events will eventually turn out, it is impossible to mix fiction with truth because the untruths would quickly become unsustainable. The only exception would be for cases of "insanity," or more specifically a pathological delusion (205).

Braud's article "'Le Texte d'un roman': Journal intime et fictionnalisation de soi" ("The Text of a Novel": Diary and Self-Fictionalization, 2002 ) is similarly limited by a narrow conception of fiction. Braud identifies two apparently autofictional diaries, but in both cases these were not "genuinely" written in an autofictional mode as diaries of present events (79). One of these, by Jean-Bênoit Puech, takes an existing, truthful diary and rewrites it, semi-fictionally, for publication. Another work, by 
Christophe Deshoulières, was written in diary form but actually covers a period of one year in the past rather than the present. In both cases, the fictionalization has been applied to past events whose development and conclusion is already known to the author. Using these two works as examples, Braud assumes that the creation of a fictional, or even semifictional, work requires that the author have an overview of the structure and conclusion of events, which precludes the composition of an autofictional diary in the present. Braud arrives at a similar conclusion to Lejeune: the diary is not only poorly matched with fiction, but positively antifictional, and especially opposed to the perceived threat of autofiction, as the diary "asserts that a literature based on the relation to reality is possible after all" (83).

Essentially, these critics are excellent readers of conventional diaries but poor readers of autofiction. They are right that, overall, the vast majority of diaries maintain a close adherence to the truth, or at least, the subjective truth of the diarist at that moment. They are also right that the diary, much like photography, maintains a strong symbolic connection to the truth, which is grounded in the everyday practices that produce it. But diaries can still be incorporated in autofictional texts precisely to make use of this symbolic attachment to truth (as indeed photographs can). Admittedly, these two critics focus on a more specific question than my own, not just whether autofiction might be broadly diaristic, but specifically whether a diary can be written in a fictional mode in the first instance rather than reworked at a later time (as Guibert often did). It is certainly difficult to write a diary that is partly fictional, but it is evidently possible, especially if we allow fiction to mean things other than the fabrication of a counterfactual sequence of events. But it is this very plurality of types of fiction that the two critics overlook, and which autofiction tends to reveal. This plurality includes, but is not limited to: the fictionality imposed on our lives by competing narratives in our cultural environment; the fictionality of our individual phantasies; and the fictionality inherent in the distancing and transformations of the literary writing process itself. All of these can be explored in the diary, without the need for the narrative coherence and closure of a novel, and perhaps all the more successfully, as the diary reveals the presence of these fictions in the fabric of our everyday lives. Furthermore, whatever the practicalities of the initial composition of these works may have been (we are given no firm assurances), both Guibert's Voyage avec deux enfants and Angot's Léonore, toujours are interested in the same question as Braud and Lejeune, but without coming to 
the same negative conclusion: they present their own experimentation with a diary written autofictionally in the first instance and explore the implications of such a possibility.

\section{Hervé GuiberT's Diaristic Writing}

Guibert found fame and commercial success in 1990 when he published his book À l'ami qui ne m'a pas sauvé la vie, which relates his experience of living with AIDS. He is probably still best known for his books on this subject from the final years of his life, and these works are important for the development of his own practices of autofictional writing. Indeed, he claimed that writing about AIDS allowed him to "radicalize a little further still certain systems of narration, of [his] relation to the truth, and the exposition of [his] self" (Guibert 1990a, 19; translation modified). This is where I took the idea of a "radicalization" of autofiction from for the title of this chapter, as this term seems to characterize the general movement toward the second generation of autofictional writing, with a fundamental shift in its orientation. Yet, Guibert's overall aim to reveal himself completely, through a complex play of truth and fiction, goes back to his first book publication in 1977 (Genon 2010, 187). Several of his works use diaries or are adapted from his principal diary, which was published posthumously in 2001 under the title Le Mausolée des amants (The Mausoleum of Lovers). He refers to this diary as the "spinal column" of his project, and the other books as "appendices" to it (Guibert 1992). The 1982 work Voyage avec deux enfants is structured around a complex diary-writing project, and it appears to have allowed Guibert, for the first time in his career, to achieve just the sort of ongoing fictionalization of himself that Lejeune and Braud considered impossible.

The central experience related in Voyage avec deux enfants is a trip to Morocco taken by Guibert, another young man, and two adolescent boys aged around 16. Guibert takes a sexual interest in one of the boys, Vincent, with whom he would later have a relationship, and who also features in several other works, including the 1989 book Fou de Vincent (Crazy for Vincent), which is largely composed of excerpts from Guibert's principal diary presented in reverse chronological order. Guibert exaggerates the youth of the boys, and pedophilia is presented provocatively as one of the book's themes. The ethics of Guibert's attitude toward pedophilia, and of his uncritical use of North Africa as a sexualized oriental setting, are 
important questions that would warrant a discussion in themselves, but which I shall only indicate here in passing.

Voyage avec deux enfants consists of three parts. Part 1 contains diary entries written before the trip. Part 2 is the diary of the trip itself. Part 3 is a single, undated passage which acts as a kind of epilogue. But the book's chronology is more complicated than this division into three parts suggests. Part 1 has the most eclectic contents, made up of diary entries covering the period when the idea of the trip was conceived and when various preparations were being made. These entries are not printed in strictly chronological order, but have been re-arranged slightly to support the artistic coherence of the book. Some comments from the author in parentheses help to explain these editorial decisions: for example, the second entry printed in the book is introduced with the words "Samedi 13 mars (car je recherche des antécédents)" (Guibert 1982, 14). There are also two undated (or rather, ambiguously dated) entries copied from a more distant period in the past, which are included for their thematic relevance (24-26, 28-31).

When the author is just eight days away from the start of the trip, he decides to start writing a diary (still within Part 1) of how he imagines it could go. He takes eight sheets of paper, marks them with the dates of the eight days of the trip, and writes as if he were already there. This "diary of anticipation" gives free rein to his imagination, and develops into a sort of fantastical story: one of the boys has been bitten by a dead man and develops a fever, a witch doctor conducts a strange and erotic ritual involving a two-headed snake, the boy wanders off in a delirium, and is eventually found in the desert. This is presented as a fiction, although it is also a phantasy (in the psychoanalytic sense) that reveals something about Guibert himself.

In Part 2 we find the diary of the real trip. The actual chronology of the entries in this diary is simpler than in Part 1 , but as we shall see, its complexity lies instead in the relation to truth and fiction. The single, undated passage in Part 3 relates how Guibert returned home to find himself now obsessed with Vincent. He asks Vincent to send him a letter. The letter that Vincent sends back to him relates an aimless trip that he made to the Paris suburbs, but Guibert describes this letter in a way that clearly functions as a mise en abyme, effectively a summary of his own book:

He himself didn't know why he had left, to what end. And then, suddenly, he knew, and he wrote it down: it was just to be able to write, to be able to 
write to me that he had left, so that this letter could be written and posted before the dawn, $[\ldots]$ as it was impossible for him to write to me from his home. (122)

This passage, standing as a description of Guibert's book, certainly does not answer all the questions we might have about it: why is it structured in this complicated way, and what is its overall relation to truth or fiction? But it does give us several indications: the journey and writing project were undertaken without a clear understanding of their nature and in ignorance of their eventual form and conclusion. These things (the project's nature, form, and conclusion) are discovered only in the course of the project itself, and notably through the writing process. One of these conclusions - both for Vincent's trip to the suburbs and for Guibert's trip to Morocco-is that the details of the journey are inconsequential, but that the journey was still necessary for allowing writing to happen and the literary work to appear. And it could not take place at home, both literally and figuratively: the book requires the real travel diary found in Part 2, but Guibert also needed to strike out from his familiar mode of writing to find something new. So, taking our prompt from this mise en abyme, let us return to the start of the book and look more closely at the various indications that the text provides regarding Guibert's experience of the writing project.

A note tells us that the plan for the journey dates back to the 14th of March (13), but the entries are not in strict chronological order, and so the first entry is from the 19th. This entry provides a description of his initial, very general imagination of the trip: it depicts a scene "between the desert and the sea" (13), where he watches the boys playing, and feels at ease in his body, which is normally a source of anxiety for him. From the outset, this places his phantasies at the center of the project, phantasies that reveal his desires and fears. Several further entries relate his preparations for the trip: these include some banal, practical steps, but also the gathering of books about travelers, explorers, flora and fauna, as a spur for his imagination, and passages in which he elaborates his phantasies in greater detail.

After a few pages, we find the entry for the 14th of March, when Guibert's friend first invited him on the trip. Guibert writes: "I was so grateful that I could have kissed him. This invitation was a gift: although I didn't know it, he was also offering me a book, which had not yet been written" (23). It is strange to find this comment in a diary entry, that the 
author did not yet know that he was being offered a book, this book that we are reading, and it suggests that some subsequent editing of the entries has taken place. We later find out that Guibert's friend had invited him because he had discovered a lost fragment of Guibert's diary, containing the following words: "Have the impression of always cutting myself off a little more from the world, whereas the aim of any creative enterprise must be to get closer to the world" (50). The trip was therefore a creative enterprise even before Guibert knew about it, and its aim is to "get closer to the world," which clearly makes his use of fiction paradoxical.

The project is also threatened with failure at various points. In one entry, Guibert is concerned to find that he has no desire for the boys and declares: "I felt all the scaffolding of the trip collapse, and therefore all the novelistic scaffolding" (31). As the writing project seems to depend on his investment in a related set of desires - for travel, for the boys, and for a new sort of book- he makes a concerted effort to nourish and develop his desires, and this leads us up to the "diary of anticipation." With eight days to go, he begins a first, imaginary diary of the trip, and describes his plans as follows:

This will be the first part of the book: a first trip will take place here, in this quiet study [...], among my books, my files, in my tranquility, my isolation. The second part of the book will be the diary of the real trip, this palinode will take place in the intermittences of harsh light and shadow, among noise, and close to the boys, their laughter [...]. It will be shorter than the first one, more breathless and contrite, perhaps less enchanted as it will be affected by exhaustion and soreness from travel, sleepless nights, disgust or hunger $[\ldots] .(33)$

Evidently, the finished book contains more than these two parts, the two diaries of the trip, yet this double structure lies at its center. The first diary is manifestly fictional, in a way that extends Guibert's phantasies into a kind of short diary novel. This is in itself a breakthrough for Guibert, as he comments, "for the first time I'm inventing, making up stories, I'm not just relating a recent event or new feeling" (50). But at the end of this diary, on the cusp of embarking on the real trip, the project is threatened once again, as Guibert feels that he has already exhausted his desires in writing, and he is "afraid to continue to be immersed in fiction, as if in madness" (62). But he does continue. 
The second diary is concerned with the real trip, yet as it turns out, we are not faced with a contrast between a fictional diary and a real diary. Instead, Guibert now attempts that "madness" (as he puts it, as well as Lejeune) of writing an autofictional diary. The opening passages of the second diary, relating the tedium of the wait at the airport and the petty misbehavior of the boys, presents a banal realism that contrasts sharply with the fantastical world of the "diary of anticipation," and while we cannot determine precisely what is true and false (any banal detail could be present merely to provide a "reality effect"), there is little doubt that Guibert's final sense of being changed by the trip and his infatuation with Vincent, as related in the epilogue, are real. But we also soon see signs of fiction, or conflicting indications of the text's truth status, and we become aware of the subtle transitions where Guibert's imagination seems to take flight. Without pausing here to document those instances, I shall observe only that the work's particular combination of truth and fiction-a fiction that is manifestly present yet impossible to localize or delimit-makes it unsettling to read in a manner that is now familiar (but no less unheimlich) from later autofictional works by Guibert and other writers of the second generation.

The important point, with regard to the relation between autofiction and the diary, is that this form of writing did not come easily to Guibert. The writing of an autofictional diary is the culmination of all his preparations in Part 1 (including the "diary of anticipation"), and crucially, in light of Lejeune's comments that such a diary could not be sustained, it lasts for only eight days. Nonetheless, it marks a breakthrough in Guibert's overall project of self-revelation and anticipates the autofictional writing that he continued to develop over his career.

\section{Christine Angot's Diaristic Writing}

The action and themes of Léonore, toujours are very different from those of Voyage avec deux enfants: the narrator relates her everyday experience of looking after her eight-month-old baby, named Léonore, leading up to the latter's sudden death, and she also frequently evokes the theme of incest. However, there are certain parallels between the two texts, both in the broad way in which they act as pivotal works in the authors' respective careers and in the specific way in which an experimental diaristic writing project is used to change the author's relation to writing. 
Like Guibert, from the start of her career Angot took an interest in the relation between life and literature, truth and fiction, the author and the textual "Christine" found within her works (Havercroft 2014, Section 2; Sadoux 2002, 171). Despite this, her first two works are manifestly fictional in their overall conception: $V u d u$ ciel (Seen from the Sky, 1990) is partly narrated by a murdered girl who is now in Heaven, while Not to be (1991), which does not feature the textual "Christine," is narrated by a man speaking deliriously from a hospital bed. Following the emergence of a certain autofictional posture in Léonore, toujours, Angot's work continued to explore the permutations of truth and fiction. It was only with the publication of L'Inceste in 1999 that she enjoyed considerable commercial success for the first time, and became a leading figure in the new generation of autofictional writers (Ferguson 2021, 680). She continued to equivocate about applying the term "autofiction" to her work (Huet 2018,203 ), but this can itself be interpreted as part of an autofictional strategy of ambiguity. Between the clear fiction of the early works and the clear autofiction (however paradoxical this might sound) of the later works, Léonore, toujours forms a bridge. It is labeled on the cover as a roman (novel), but from the beginning the narrator rejects her former novelistic writing and commits instead to a form of private, diaristic writing rooted in her (apparently) real everyday experience. Yet, the narrator's commitment to truth is undermined throughout the book, and the final section relating the death of the child is revealed to be a pure fabrication (there are signs of its fictionality within this work, and Angot's later books continued to be dedicated to her daughter, the real, living Léonore). Critics have mainly approached Léonore, toujours through its principal themes of maternity and incest, which are recurrent in Angot's work and closely connected to the nature of her writing. ${ }^{2}$ These themes are undoubtedly connected to the pivotal role of Léonore, toujours in Angot's career, but I shall focus here exclusively on the way in which an experiment in diaristic writing is used in Angot's own, individual invention of an autofictional writing practice.

The first indication of Angot's project is found in the epigraph, taken from a letter written by Mme de Sévigné dated February 25, 1671: "It seems to me that I betray my sentiments in wanting to explain them in words; if only you could see what happens within my heart when I think of you" (Angot 1993, 9). Whereas the generic label on the front cover has told us to expect a novel, we are now faced with a form of everyday, private writing, addressed from a mother to a daughter, which expresses the 
classic topos of the inability of writing - or of explanation through established forms of discourse-to reveal the truth of our interior experience. Immediately after this epigraph, the opening of the main text, which is made up of 24 dated diary entries, sets out with remarkable concision the circumstances for Angot's own attempt to find some new form of expression:

I gave life. It killed me, I only had one. I'm no longer writing. Since today. This isn't called writing [écrire], it's called marking [marquer]. I'll mark something about her every day, at least a line. There's only her. Only that. That. Which killed me. / She's called Léonore. It's not yet seven o'clock, she's still sleeping. Because this girl, this little girl, is a dream. (11)

The narrator's experience of maternity, presented here as a traumatic loss of self and subjectivity, as one "life" is now being shared between both mother and daughter, has made her former writing practice untenable, and she resolves to replace this writing with something else, a diaristic practice that she calls "marking." It is worth dwelling on the two terms in this opposition that frames the new project, between the rejected écriture and the new "marking."

The concept of écriture is variously associated with the public role of an écrivain (writer) who writes books related to contemporary social issues (she had previously been working on "something on Iraq" [12]), the practice of writing as the "hard labor" (13) of producing the "composition" and generalization of a work intended for others (150), and above all the prospect of the novel as an end product. ${ }^{3}$ Whereas the narrator of Léonore, toujours used to feel desire for the novel, it now inspires feelings of disillusionment, and even shame (45-46). Writing a novel is not only practically incompatible with the constant distractions of motherhood (19-20), but it is also "an activity for people without children, who could commit suicide"; in other words, she now finds herself fundamentally more attached to life. Conversely, the new strategy of "marking" is initially based on a simple writing practice suggested by another parent: "Claudine asked me 'are you marking?', making a writing gesture, today first tooth, today first smile, first proper sounds" (13). However, drawing on certain longstanding mythic ideals of authenticity and immediacy associated with the diary, ${ }^{4}$ the narrator elaborates a broader conception of this diaristic practice that responds to every negative aspect of écriture mentioned above. It is supposedly a form of private writing intended only for herself 
(49), produced "spontaneously" (48), as a material trace of details of her and her daughter's life (13), or as a sort of bodily secretion that preserves her feelings, thoughts, and love (54). ${ }^{5}$ The privacy of her marking gives her the right to say what she likes and acts as a proof of her sincerity (20-21), while this "direct" writing in the present moment (26) allows a close contact with the banal reality of her everyday life with Léonore ("I can taste the monotony of the days," 46). This initial opposition between the rejection of écriture and the commitment to a diaristic ideal of "marking" tells us a great deal about the author's autobiographical desires, but it also seems to be an impossible goal, and indeed to be contradicted by the fact that, as readers, we hold in our hand a published literary work that is labeled a novel. In practice, the interest of the writing project found in the book lies in the evolution of these terms as the diary progresses toward the final reversal that brings the project to an end with the fictional death of the narrator's child.

We can see this evolution first as a series of compromises that seem to abandon the ideals of "marking," and then as the narrator's return to a revised concept of écriture. The idea that she is writing the diary completely privately and spontaneously is steadily eroded: the narrator evokes a series of readers, including Léonore and the narrator's partner Claude (16-17), but also as an écrivain she cannot help writing for a general reader (14, 47-48). There are also "others" upstream of her writing process: just as Guibert's writing was inhabited by the influence of Thomas Bernhard (Guibert [1990b] 1999, 233), Angot's writing is inhabited by Guibert and accommodates another narrative voice by including excerpts from Claude's earlier diary which trace their lives together in the years leading up to Léonore's birth. It soon becomes apparent that this "marking" is not a passive record of the narrator's experience, but rather a part of this experience with consequences of its own, such as when she takes actions while anticipating how she will write about them (e.g., she inserts her daughter's fingers in her own mouth while thinking of the effect this will have when it is recorded in the diary, 17).

The narrator eventually acknowledges that the "marking," as it was initially conceived, had lasted for only a few days, and has since been replaced by a form of écriture (123). This change is partly manifested in the presence of some of the same types of fictionality that we saw in Guibert's work: she relates a series of phantasies connected to her complex feelings toward Léonore-several scenes of a grown-up Léonore having sex (29-31), the adult Léonore sadistically murdering the narrator's 
abusive father (53), or a vision of Léonore's corpse in a rubbish bin (90)and she also reveals her own deception of the reader, such as when she transcribes a poem that she claims to have written, then later admits that she copied this poem from elsewhere (50-51, 79-80).

As it gradually becomes apparent that the passive recording of "marking" has transitioned to the hard labor or "torture" of writing (129), the diary-narrative reflects on the possibility for this text to become a livre (book), or even a novel. This includes the practicalities of accumulating a sufficient number of pages, sending a sample to her publisher, and the discussion to which this sample gives rise $(115,119,132)$. It also involves increasingly detailed reflections on the apparent contradictions of her project: that the apparently truthful diary itself is a world built of its own conventions and fictions, by which she aims to depict the real Léonore, to "imagine a whole life, her life, in a book" (122), and that, despite her decision to publish, "it's still true" (137). These reflections eventually conclude with the following claim, suggesting that a complete reversal has taken place relative to her previous writing practice:

In [Claude's] view, since I've finished with novels, there's no écriture. It's exactly the opposite. It's now beginning. Since Léonore it's beginning, on a real being. $[\ldots]$ There's before her and after her. Since she appeared, composition is ridiculous. (150)

This affirmation, that her écriture is really only beginning now that it is grounded in reality, in a real person, and written in a diaristic mode rather than in a mode of novelistic "composition," immediately precedes the final passage, fictionally depicting Léonore's imagined death.

Unlike the phantasies related earlier in the text, this passage is not explicitly presented as nonfactual, although there is an abundance of more oblique signs that this passage is a fictional creation, which is required by the logic of this text in order to provide a conclusion that inaugurates its existence as a livre. Quite implausibly (in light of the parents' evident devotion to their child), the narrator and Claude feel a "strange joy" and "solemn tenderness" (153) as they allow Léonore to die from an accidental head injury instead of seeking emergency care, and the text's final words, "Léonore, toujours," produce a sort of literary transcendence for this sacrificed, textual Léonore (155). Indeed, a series of earlier passages in the book portend Léonore's death in terms that suggest that it is linked, on a metatextual level, to this final transformation $(69,78,123)$. Huet 
(2018, 236-237) summarizes a range of interpretations that critics have made of this ending, in connection to the themes of incest, maternity, and as a response to the narrator's initial sense of having to give up her life to Huet, but with regard to the role of this passage as a resolution to the diaristic writing project, two general viewpoints are possible. On the one hand, the ending can be viewed as marking the failure of the diaristic project, as the only way for the diary to be concluded and so become a bookgeneralizable and consumable by others-is by imposing a conclusion that is a complete fiction, alien to the diary's adherence to truth and its ongoing, monotonous temporality. From this perspective, the ending is a vindication of the position that an autofictional diary is simply not possible. But this privileging of the conclusion amounts to treating the text as an argumentative essay rather than a literary work. Alternatively, we can consider that the text begins and ends with modes of writing that are equally impossible for the diary, but between the two of them they create the textual space and time ( 24 days) for this writing experiment to take place, where the modalities and limits of this hybrid form-the autofictional diary, or a diaristic autofictional writing-can be explored. A brief look forward to later works by Angot and other autofictional writers can leave us in little doubt that this second interpretation is to be preferred.

Guibert's and Angot's individual inventions of their own forms of autofiction provide us with several responses to that critical position that views the diary as essentially "antifictional." First, in practical terms, it is indeed difficult to write a diary that is both truthful and fictional, but this is mitigated when the dimensions of the diary project are defined and structured in advance, including its duration (just eight days in Guibert's case), its main topic (Guibert's trip and Angot's experience of maternity), and its themes. For Guibert, these themes include the fictive aspects of his own life, the nature of his writing (with the prospect of drawing him into a closer engagement with the world), and the goal of producing a literary work from his life. Alongside Angot's focus on the themes of maternity and incest, she too is focused on developing a new writing practice that would be adequate to the changed relationship between herself, her writing, and the world. And this shared search for new forms leads us to the question of the appeal of the diary for writers of autofiction and why they are willing to engage in this "madness": compared with an autobiographical mode of writing, the diary allows a writer to be more directly invested in an ongoing writing process that has high stakes for their relation to the 
world and to others. It is a dangerous undertaking, which was only a theoretical possibility, or even impossibility, for the earlier generation, but which has become a reality from Guibert's generation onward.

\section{Notes}

1. All translations from French are my own except when indicated otherwise.

2. On the relation between maternity and writing in Léonore, toujours, see Marie-Noelle Huet (2018, 193-237), who also summarizes the approach of other critics. Arnaud Genon explains that, for Angot, "writing is an impulse that tries to fill the original fissure constituted by incest, which is omnipresent in her work before the novel entitled L'Inceste" $(2013,16)$.

3 . The rejection of a certain stereotype of the novel has become a topos of autofictional writing. For example, see Chloé Delaume's rejection of "the neo-realist novel" or formally straightforward books devoted to "a neat little social problem" $(2010,111)$.

4. I have discussed elsewhere these mythic ideals of the diary and the impossibility of realizing them in any absolute way (Ferguson 2018, 4-8, 12, 25-26).

5. Camille Laurens emphasizes the origins of autofictional writing in the body, drawing an etymological link between "secrets" and "secretions" $(2010,28-29)$.

\section{Works Cited}

Angot, Christine. 1993. Léonore, toujours. Paris: Gallimard.

Braud, Michel. 2002. 'Le Texte d'un roman': Journal intime et fictionnalisation de soi. L'Esprit créateur 42 (4): 76-84.

Colonna, Vincent. 2004. Autofiction et autres mythomanies littéraires. Paris: Tristram.

Delaume, Chloé. 2010. S'Écrire mode d'emploi. In Autofiction(s): colloque de Cerisy, ed. Claude Burgelin, Isabelle Grell, and Roger-Yves Roches, 109-126. Lyon: Presses universitaires de Lyon.

Ferguson, Sam. 2018. Diaries Real and Fictional in Twentieth-Century French Writing. Oxford: Oxford University Press.

- 2021. Autofiction: Writing Lives. In The Cambridge History of the Novel in French, ed. Adam Watt, 671-687. Cambridge: Cambridge University Press.

Genon, Arnaud. 2010. Hervé Guibert: Fracture autobiographique et écriture du sida. In Autofiction(s): Colloque de Cerisy, ed. Claude Burgelin, Isabelle Grell, and Roger-Yves Roches, 187-206. Lyon: Presses universitaires de Lyon.

- 2013. Autofiction: Pratiques et théories. Paris: Mon Petit Éditeur. 
2014. Roman, journal, autofiction: Hervé Guibert en ses genres. Paris: Mon Petit Éditeur.

Guibert, Hervé. 1982. Voyage avec deux enfants. Paris: Minuit.

- 1990a. "La vie sida." Interview by Antoine de Gaudemar. Libération, March 1, 1990. Cited in Jean-Pierre Boulé, Hervé Guibert: Voices of the Self (Liverpool: Liverpool University Press, 1999), 196.

—. 1992. "Je disparaîtrai et je n'aurai rien caché...." Interview by François Jonquet. Globe, February. Cited in Arnaud Genon, Roman, journal, autofiction: Hervé Guibert en ses genves (Paris: Mon Petit Éditeur, 2014 ), 52.

-. (1990b) 1999. À l'ami qui ne m'a pas sauvé la vie. Paris: Gallimard.

Havercroft, Barbara. 2014. Le Refus du romanesque? Hybridité générique et l'écriture de l'inceste chez Christine Angot. Temps zéro 8.

Huet, Marie-Noelle. 2018. Maternité, identité, écriture: Discours de mères dans la littérature des femmes de l'extrême contemporain en France. PhD diss., Université de Québec à Montréal.

Laurens, Camille. 2010. Qui dit ça? In Autofiction(s): Colloque de Cerisy, ed. Claude Burgelin, Isabelle Grell, and Roger-Yves Roches, 25-34. Lyon: Presses universitaires de Lyon.

Lejeune, Philippe. (2007) 2009. The Diary as 'Antifiction.' In On Diary, ed. Jeremy Popkin and Julie Rak, trans. Katherine Durnin, 201-210. Manoa: University of Hawai'i Press.

Picard-Drillien, Anne-Marie. 2010. Martyres de la cause du moi: Écriture et inconscient de l'autofiction. In Autofiction(s): colloque de Cerisy, ed. Claude Burgelin, Isabelle Grell, and Roger-Yves Roches. Lyon: Presses universitaires de Lyon. Supplementary article published online. https://doi.org/10.13140/ RG.2.1.2456.5203.

Sadoux, Marion. 2002. Christine Angot's Autofictions: Literature and/or Reality? In Women's Writing in Contemporary France: New Writers, New Literatures in the 1990s, ed. Gill Rye and Michael Worton, 171-181. Manchester: Manchester University Press.

Sarkonak, Ralph. 2000. Angelic Echoes: Hervé Guibert and Company. Toronto: University of Toronto Press. 
Open Access This chapter is licensed under the terms of the Creative Commons Attribution 4.0 International License (http://creativecommons.org/licenses/ by $/ 4.0 /$ ), which permits use, sharing, adaptation, distribution and reproduction in any medium or format, as long as you give appropriate credit to the original author(s) and the source, provide a link to the Creative Commons licence and indicate if changes were made.

The images or other third party material in this chapter are included in the chapter's Creative Commons licence, unless indicated otherwise in a credit line to the material. If material is not included in the chapter's Creative Commons licence and your intended use is not permitted by statutory regulation or exceeds the permitted use, you will need to obtain permission directly from the copyright holder. 